\title{
FROM A SUPPRESSED ANTI-COMMUNIST DISSIDENT MOVEMENT TO A GOVERNING PARTY: THE TRANSFORMATIONS OF FIDESZ IN HUNGARY
}

\author{
MÁTÉ SZABÓ ${ }^{1}$
}

\begin{abstract}
FIDESZ, as an outlawed protest movement of the Kádár era, has preserved their specific type of "outlawed and clandestine" political tradition and identity. A strong anti-communism, a popular mobilizing strategy and an atmosphere of hatred towards the agents of Hungary's communist past remained within the political culture of the party from the suppressed underground movement. The political generation of leading activists, including current Prime Minister Viktor Orbán, has been socialized in the "underground" of the eighties. The experience of "being outlawed" under the Communist system has had longlasting effects on them. The "myths", symbols, and "fights" of the suppressed protest movements keep themselves alive in the new political culture in the present goals and strategies of FIDESZ-MPP. The former protest movement transformed itself into a minority party with liberal affiliations in the new parliament of 1990 . However, as the Hungarian Liberal Party (SZDSZ) moved into a governing alliance with the successor to the Communist party, FIDESZ moved to the right, becoming its leading force. Competition between five centre-right parties led to FIDESZ's control as the leader of a centre-right government (1998-2002). While the socialists (MSZP) and liberals (SZDSZ) became governing forces twice (20022010), FIDESZ became a mobilizing populist party, gaining hegemony within the parliamentary and extra-parliamentary opposition. The economic and financial crisis assisted FIDESZ in mobilizing protest, leading the FIDESZ-KDNP alliance to a two-thirds majority victory in the 2010 elections.
\end{abstract}

KEYwORDS party, mobilization, protest, opposition, dissidence, populism, hegemony

\footnotetext{
1 Máté Szabó is professor of political science at the Eötvös Loránd University, Faculty of State and Law; email address:mateloc@ajk.elte.hu. The author would like to express his thanks to Ágnes Lux, Ph.D. student at the ELTE Political Science Doctoral School, for her kind help in preparing this manuscript and its material.
} 
The general elections in Hungary in the spring of 2010 resulted in an overwhelming victory for the FIDESZ-MPSZ party (see tables 1-4). By taking more than two-thirds of all seats, it has an absolute majority and is able to define all political positions, as evidenced by the country's changed constitution in April 2011. Where does FIDESZ come from (Bozóki, 1992)? It was formed from members of the Budapest "samizdat" scene in the 1980s and during the transition of the system became a political party in 1988 using its protest culture in different but efficient ways as a party of mobilization. My thesis is that the active protest roots of FIDESZ led the party to employ a mobilizing party strategy, while both serving in opposition and in a governing role. As a result, an influential mobilizing-populist party has emerged from the sub-cultural student movement (Bozóki, 1988) within the framework of party competition and party system development. We analyze this transformation, which has been in progress for more than twenty years, from a suppressed informal underground group to a governing party with huge voter support.

In Hungary, based upon the law regarding associations and political parties from 1989 onwards, different organizational forms are provided for „challenging groups” as in every pluralist democracy (Körösényi et al., 2009). New characteristics of civic activism emerged within the pluralistic structural opportunities of the new political system after the Kádár era. Within the constitutional democracy, public mobilization and protest were transformed into legally and constitutionally regulated and accepted political institutions. Within the framework of the freedom of association and gathering, legal and public networking, resource mobilization and non-violent protests were born as widely accepted forms of political action.

FIDESZ, as an outlawed protest movement of the Kádár era, preserved their specific type of "outlawed and clandestine" political tradition and identity. A strong anti-communist core, a popular mobilizing strategy and an atmosphere of hatred towards the agents of Hungary's communist past remained within the political culture of the party from the suppressed underground movement. The political generation of leading activists, including current Prime Minister Viktor Orbán, has been socialized in the ,underground” of the eighties. The experience of "being outlawed" in the Communist system has had long-lasting effects on them. The „myths”, symbols, and „fights” of the suppressed protest movements keep themselves alive in the new political culture with regard to the present goals and strategies of FIDESZ.

During the nineties, most of the leading personalities of FIDESZ, including the president and the board - the core decision makers - had had a "record" of activism before 1989. Meanwhile, at the rank-and-file level, a wide range of supporters from every different political generation and grouping 
- including former Communists - joined the group of supporters after 1989. The concentration of power and prerogatives in the hands of the former underground "martyrs" in the leadership and the professional activity of the "newcomers" characterized the division of labor within the party. After 1989, a new generation of professional activists had become dominant, but at the level of the main leaders the goals and culture from the legacy of anticommunism from the period before the regime change were preserved. This was accelerated by the development of FIDESZ as the leading and unifying force of the center-right, whose main enemy became the reformed Socialist Party. This sharp left-right division preserved the "culture of resistance" within FIDESZ against former communists and ensured that their heritage was framed by the FIDESZ leadership against their main enemy, the Hungarian Socialist Party (Körösényi et al., 2009). Although the different forms of civic protest did not lose their importance after 1989 within the new party, protest became only one of the forms of political activity.

After 1989, public relations work, fundraising, national and international networking, professional education and the development of organization and management for professional campaigning and voter mobilization were of eminent importance among FIDESZ activists and professionallytrained employees were required for producing efficient services. After 1989, pragmatic and policy-issue-oriented approaches became the dominant approach. Six national and local elections and a period of government from 1988 to 2002 transformed the former student protest group network into a professional center-right party, maintaining itself in the professionalized political-administrative system of representation and governance (Körösényi et al., 2009). These processes of bureaucratization and oligarchialization, as well as professionalization during the transformations of modern social movements into political parties were analyzed by Max Weber and Robert Michels (Zald 1990) at the beginning of the twentieth century. However, later social research made a distinction between the development of organizational structures, goals and programs and strategies development, challenging the Weber-Michels paradigm (Zald 1990). According to these findings, professional bureaucratic party organizations may preserve radical goals and a conflict-oriented culture from their pasts as social movements, which seems to be the case with the development of FIDESZ in Hungary. 


\section{THE THREE FACES OF FIDESZ: DISSIDENT MOVEMENT, POLITICAL PARTY, AND MOBILIZING-POPULIST PARTY}

In analyzing the political changes within FIDESZ, one has to differentiate between the political mobilization of the masses and the mobilization of social movements and organized political behavior within a political party.

We may differentiate the following stages within the development of FIDESZ:

- FIDESZ as a dissident movement between 1988 and 1990;

- As a party established in 1990, and a member of a growing multi-party system which rejected a mobilizing strategy in 1992;

- It's role as the leading force of the centre-right from 1992-1998;

- The stage of adoption of a top-down mobilization strategy by FIDESZMPP in popular government campaigns between 1998 and 2002;

- FIDESZ-MPSZ after the 2002 elections as it became a mobilizingpopulist party of right-wing opposition, further accelerated by sharp nonparliamentary conflicts starting with the 2006 Autumn riots;

- FIDESZ when it regained control of the government in 2010.

Hence, this 2002-2010 mobilization is different from the ones of 19881992 because it is based on a nation-wide organizational network, as a former governing party (in terms of material and personal resources) with a new type of populist orientation and a civil society which can be addressed within the system of political pluralism (Ekiert-Kubik, 1998). In 1988-1992 however, transition occurred within the social, economic, and political systems; there were uncertainties about the roles and differences between parties and movements, between the existence of a unified civil society supporting democratic transition beyond authoritarianism or a political party within a pluralistic spectrum (Ekiert, 1991). So, within the development of FIDESZ to FIDESZ-MPSZ we can see a change from a bottom up to a top down mobilization strategy, from a social movement to a party, from civil to political and from an NGO to a government organization. Based on these developments, the FIDESZ organization and strategy in 1988 played an avant-garde role in the change of system in Hungary, and later on followed the models of right-wing populist parties in Europe. 


\section{FIDESZ AS A DISSIDENT MOVEMENT}

The protest tradition we had in Hungary before 1989 was one which consisted of younger, urban, professional, white-collar workers, especially students, artists, scientists, clerks, social workers, and educators; it was "dissent" and "opposition" natured. Protest was concentrated in the capital, in Budapest, and in some bigger university towns such as Pécs, Szeged, and Miskolc (Schöpflin, 1979).

The share of youths in protests in Hungary was one of the highest among the Central European communist countries (Ramet, 1991). Younger people, especially students in higher education, are generally more likely to be mobilized in modern societies than established professionals with jobs and families. Younger people are more inclined to accept risky situations and have fewer boundaries and more free time and energy than workers and employees. Students were clearly dominant at protests in the eighties in Hungary, fighting for ecology, peace and human rights issues, although some of them were expelled from university, hindered in travelling abroad, or forced to enter military service, not to mention being subjected to other, 'lighter' forms of repression (Haraszti, 1990; Miszlivetz, 1989). Youths and students who mobilized in 1989 took their reference points from the Hungarian revolutions of 1848 and 1956 when youth and students played a leading role (Tőkés, 1998).

The young, educated, mobile personalities and networks of the anticommunist dissidents seemed similar to the supporters and the constituencies of the "new social movements" and Green parties of the eighties in Western Europe (Judt, 1988; Ramet, 1991). However, these western movements from the eighties were allies of left-libertarian parties, which were active in the peace, ecology, and autonomy movements, as well as in fighting peacefully for different social goals, from gay rights to squatting. Being critical of the market economy and bureaucracy were their common attributes. Meanwhile, autonomous social activism within the former Eastern Bloc countries rejected the planned economy and the bureaucratic-gerontocratic Communist structure (Szabó, 1991; Knabe, 1989). The eastern activists moved from alternative Marxism towards liberalism; the Western social movements from the New Left to alternative ecology and New Age. Eastern movements preferred the market economy and representative democracy; autonomous Western movements criticized consumer society and the crisis which stemmed from the adoption of western values and institutions. The goals and cultures of the social movements of the eighties were different in Eastern and Western Europe, though they shared some common points such as the focus on peace, ecology and human rights (Pollack-Wielghos, 2004). 
FIDESZ was one of these radical anti-communist movements established within the crisis of the Eastern Bloc, bound to the western values of the market economy and human rights while opposing the legitimacy of the leftist ideology of the former communist regime. FIDESZ never had the tradeunionist character that Poland's Solidarnosc had (Arato, 1992; Ekiert-Kubik, 1998), but it shared the value of national identity and self-determination against the forced communist internationalism of the Eastern Bloc. In Hungary, a special engagement with Hungarian language minorities (estimated at being between two to three million in number) was combined with rejection of Communist internationalism. As a result, nationalism, national minorities and self-determination shaped the political universe of FIDESZ, which was very different from the cosmopolitanism and global solidarity values of Western "new social movements" (Joppke, 1994).

FIDESZ was established on the basis of the former autonomous student movement and organized protests against the communist system from 1988 onwards. Of all the Hungarian political parties, they organized the most protests in the first legislative period of 1990-1994; primarily in the years between 1989 and 1992 (Ekiert -Kubik, 1998). Later on, the popular leader of the party, Viktor Orbán, launched a new strategy for gaining constituencies among all strata of the population. The party abandoned its former 35-year age limit for membership in 1992, gave up their intensive protest strategy and created a right-wing, pro-establishment reorientation with a focus on the public sector and high mobilization of youth and students (Mudde-Kopecky, 2002-2003). The party lost its provocative, protest character, and groups that wanted to preserve their former identity were leaving or were pushed out by the centre-oriented mainstream by 1993 .

\section{FIDESZ AND PROTESTING: A POLITICAL PARTY SEARCHING FOR ITS OWN POSITION AND IDENTITY}

The protest activity of the parties of the first Hungarian parliament of 19901994 was examined within the framework of an international comparative project on protest behavior (Ekiert-Kubik 1998). Of the parties in the first parliament, FIDESZ is ranked as being the most active in the politics of protest between 1989 and 1994 (Machos, 1993). However, if we look at the distribution of these protests, all the events took place in the first three years (1989-1991) of the period investigated. FIDESZ completely left the 'market' for protest after that year. There was a change in party strategy and direction regarding social movements - especially the youth and alternative 
movements - as they were pushed out of leading positions in the party. The activities of FIDESZ concentrated exclusively on parliamentary activity and they tried to escape their past as an anti-communist social movement through highly conformist political behaviour within the new institutions. FIDESZ ended its protest politics against the communists within the first years of democratization and did not participate in the campaigns of the liberal SZDSZ and the socialist MSZP against the MDF-led Christian-democratic government (Bozóki, 1999-2000).

Originally, FIDESZ institutionalized a new political generation of Hungarian opposition: FIDESZ as a liberal party with a membership age limit of 35 in the eighties; while SZDSZ had the support of the older generation. FIDESZ was strongly affiliated with the Hungarian student, ecology and peace movement activists, whereas SZDSZ was based on the liberal groups of 1956 veterans and the traditions of Hungarian dissent, the "Budapest School", the Georg Lukácscircle and the civil rights opposition of the seventies and the later "samizdat" circles (Kende-Smolar, 1989). The different political traditions moved the two parties in different directions: SZDSZ remained more liberal-oriented while FIDESZ tried to be "pragmatic" and power-oriented, seeking alliances with nationalist parties. SZDSZ had and still has a strong tendency towards social liberalism, meanwhile FIDESZ merged the first patterns of liberal conservatism with alternative orientations (ecology, feminism, youth movements) and then with Hungarian nationalism and a Third Way orientation. The differences between the two parties were increasingly based on the different quality of political values and orientations of the political generations, and not their ages. In 1992 FIDESZ abolished its membership age limit, but despite the inclusion of older generations the party maintained the political values, strategies and organizational forms which differentiated it from SZDSZ. The two parties, both coming from anti-communist protest movements, were different from each other in their leadership and professionalization dynamics. Within SZDSZ, the founders, with their political culture of the "clandestine" and "underground" movement were pushed out of the party leadership in favor of professionalized types of technocrats who took their place and did not have "catacomb" (underground) backgrounds. In FIDESZ, the "Founding Fathers" maintained their continuity in the core group of the party leadership (Csizmadia, 1995), and they themselves became professional politicians and technocrats.

The younger generation of movement activists who were never "outlawed" for a longer period of time could fit into parliamentary politics; while a significant part of the older protest generation, having been persecuted for a longer period, left the professionalized political scene behind in order to uphold their original creative intellectual professions and roles. 
Sources of internal differentiation and conflict among intra-party groups with different values and strategies within the two parties were also based on their different strategies and relations towards other social movements. In FIDESZ from the beginning there was an internal division between "movementists" - the socially-engaged, direct-democracy participation-oriented line - and technocrats, who supported professionalization, the market economy and representative democracy led by Viktor Orbán, the popular leader of the party. The "movementists" tried to maintain direct, "basic" democratic elements within the party organization and supported the civil rights activism of social movements' peace and ecology campaigns. This orientation was gradually pushed down within FIDESZ through a pragmatic and power-oriented focus, and the final fight occurred in 1993 with the victory of the Viktor Orbán-led FIDESZ.

The direction of the losers" "exit" from FIDESZ in 1993 shows the clearcut difference between SZDSZ and FIDESZ in their strategies towards social movements. At the beginning of the 1990s, Viktor Orbán argued, even on a general level, for a "political monopoly" of political parties in parliamentary politics and blamed both left and right non-parliamentary movements which had competed with political parties on the Hungarian political scene. SZDSZ also had its internal debates and leadership conflicts along the "movement versus party" front, but in contrast to FIDESZ, even the party's technocrats lost their positions and SZDSZ preserved its openness towards social movements and political protest. This led to the fact that during the taxi-driver blockade in October 1990, FIDESZ rejected the protest, while the leaders of SZDSZ, based on their experience of "resistance" against the communist system demanded that the government withdraw in the face of the protest. This type of "extra-parliamentary" engagement was preserved in SZDSZ and diminished in FIDESZ during the 1990-1994 legislative period (Bozóki 1992).

FIDESZ, after its strategic and personal reorientation in 1992-1993, increasingly became a supporter of the church and nation (Mudde-Kopecky, 2002; Falk, 2003). FIDESZ grew from an alternative party into a liberal one from 1988 to 1992, and from a liberal party to a centre-right, Christian, populist one between 1992 and 1998. FIDESZ-MPP changed its membership at the European level, and quit the European Convention of Liberal Parties for that of the Christian Democrats. Its alliance structure changed: first, FIDESZ backed SZDSZ, but after SZDSZ became a member of the governing coalition with the Socialists in 1994-1998, FIDESZ found solidarity with the right-wing opposition party bloc and sought to build more and more efficient coalitions and cooperation with them, using their constituencies in its own interest. 


\section{FROM FIDESZ TO FIDESZ-MPP: TAKING THE LEAD OF THE CENTER RIGHT}

At the general elections in 1994, FIDESZ won seven percent of the votes cast for party lists and sent twenty representatives to Parliament (Table 1). Following the elections, the entire party leadership resigned and they tried to analyze the causes of the party's failure at the elections, which are summarized in the document "From Opposition into Opposition". Orbán was re-elected as a party chairman with a solid majority.

At the local autumn elections, which were changed to a single-round election by the governing majority, FIDESZ had several joint candidates with MDF and KDNP, taking 284 seats alone and 370 seats with coalition partners. The party delegated mayors in seven principal cities (four of them municipalities), in three Budapest districts, and in fifteen smaller towns.

At the Seventh Party Congress in late April 1995 (held in Budapest) the delegates decided to change the name of the party to the FIDESZ-Hungarian Civic Party. They also adopted the slogan "For a Civic Hungary" which stated that FIDESZ was a liberal, civic party. The congress elected Orbán as chairman for the third consecutive time. Orbán raised the issue of a three-party Civic Alliance between FIDESZ, MDF and KDNP because, in his opinion, that was the only possibility to create an alternative to the coalition of MSZP and SZDSZ which held an overwhelming $72 \%$ majority in the Parliament.

Orbán, as chairman of the FIDESZ-Hungarian Civic Party, and Sándor Lezsák, chairman of MDF, started negotiations in May regarding cooperation between the two parties. The number of FIDESZ parliamentarians increased by thirteen people (from the then disbanded KDNP parliamentary group in September, and by former MDF MP László Salamon, who joined FIDESZ after the 1996 split within MDF). Thus, with a total of 34 MPs, FIDESZ became the biggest opposition party in parliament, and was entitled to nominate one of the Parliamentary vice-chairmen, selecting János Áder. Zoltán Pokorni was chosen as the new leader of the party's parliamentary group. In October, the National Board of the party adopted a resolution calling on FIDESZ to complete an agreement with MDF which would allow for successful participation at the following year's general elections. This agreement was signed at the end of the year. FIDESZ reached a similar agreement with the organization that had left KDNP, the Hungarian Christian Democratic Alliance (MKDSZ), which had joint candidates with FIDESZ in individual constituencies as well as candidates who had been put on the party lists of FIDESZ.

At a meeting of the party's regional leaders in mid-December, Orbán declared that the conditions for cooperation between civic political forces had 
been met and the flagship of this cooperation was FIDESZ. The chairman introduced a list of people - many of them experts from outside the party who were responsible for the field of policy. They were largely the people who were charged with preparing FIDESZ for government, and those who were to become ministers if FIDESZ claimed victory in the elections.

\section{FIDESZ-MPP AS A POPULIST AND MOBILIZING PARTY}

The occurrence of political demands formed during the protests in Hungary was subject to political changes. The political character of protests diminished in the election years of 1990, 1994, and 1998, when political issues were highly integrated in these respective campaigns (Körösényi et al., 2009). The high level of politicization in 1989 was rooted in the political conflicts of the regime change, while the one in 1991-1993 was based on the political polarization of pro-government and anti-government initiatives and organizations. One of these initiatives, for example, related to the media and the question of religious education in schools. 2002-2006 was a peak point for protest from the Right which leveled the accusation that parliamentarism and constitutionalism were being manipulated by the Left and winning the elections was being accomplished through a clandestine conspiracy of Communism and Capitalism.

This type of demand was first raised in 1994 following the rhetoric of the electoral campaign, but it did not increase dramatically. At that time, the campaigning right-wing parties did not need to extend their campaign to include the protest politics of civil society; their approach remained mainly within the framework of the electoral campaign. This changed dramatically in 2002 when FIDESZ-MPP, parallel to its electoral defeat, opened itself up to "citizen's initiatives" (Citizens' Circles) from the right, which supported its policy of demanding a recount of electoral votes, urging the stepping down of the new government and the holding of new elections. In 2002, after criticizing the mobilization strategy of SZDSZ against the government in 2002, FIDESZ-MPP declared its own new mobilization strategy and opened itself up to civil society in an attempt to redress its electoral failure.

As we have seen, FIDESZ/FIDESZ-MPP changed a lot of hats in moving from being a dissident sub-cultural democratic movement until it became the centre-right governing party from 1998 to 2002. Some elements of its development were combined speedily and successfully in order to engineer its new image and organization under the pressure of the electoral defeat 
of May 2002 which brought the MSZP-SZDSZ social-liberal coalition to power in the summer of 2002 (Table 1). FIDESZ-MPP as a governing party within the centre-right coalition acted like a "populist" government; it stressed the "national" and the "popular" (Glenn, 2001; Mény-Surel, 2002) character of the government coalition and organized government meetings in small unknown villages while Viktor Orbán, as a strong Prime Minister, behaved as if he had direct links with the masses, acting as a "popular leader". However, having already tasted electoral defeat during the two 2002 election turnouts, the situation lead FIDESZ-MPP to become a mobilizing populist party that targeted and challenged "them", the "communists" who came back, as they did, by winning at the polls in 2002. As a result, FIDESZ-MPP tried to quickly reassert its image as the anti-communist dissent movement, as it indeed was from 1988-1990.

In February 2005, in his annual "state of the nation" speech, Orbán called for the year to be centered around "consultation". A National Consultation Body consisting of conservative intellectuals was set up in March; the consultation team toured Hungary throughout the whole summer and sent questionnaires to every citizen in the country.

In 2005, the mandate of the President of Hungary ended and - in accordance with the Constitution - a new head of state had to be elected by the Parliament. The internal problems of the governing parties and tensions within the coalition (which had only a ten-seat majority in Parliament) led to the victory of the opposition. In the final (third) round of voting, a civic candidate, László Sólyom, got the necessary support from FIDESZ MPs and in August took office as President of Hungary. On June 11, 2005, Viktor Orbán was re-elected as the chairman of the party.

As the "Civic Governance 2006" program advanced, conferences on specific policies were organized from 2005 on. In preparing for the 2006 elections, the party emphasized its pragmatic profile. Although in 2002 it seemed that FIDESZ and MDF would continue with the partnership they had been engaged in following the EP elections where the smaller opposition party distanced itself from FIDESZ, it was clear that a new strategic ally was needed as the election date came closer. Thus FIDESZ opted for a new partner: whereas in 2002 it presented its candidates on a joint list with MDF, the small party's hostile attitude toward the leader of the opposition this time resulted in a strong bond between FIDESZ and the Hungarian Christian Democratic People's Party (KDNP), with whom a joint list for the coming elections was agreed upon. KDNP leader Zsolt Semjén and Viktor Orbán signed an agreement on cooperation which meant that, with the exception of two individual constituencies where the three opposition parties supported the 
same candidate, FIDESZ and KDNP would cooperate effectively, while MDF had its separate candidates in every part of the country.

FIDESZ held its nineteenth congress in March, when Chairman Viktor Orbán was unanimously voted to lead the party and was elected candidate for prime minister. The official electoral program of FIDESZ was also adopted and Orbán announced that the party would host a grand rally on Kossuth Square on April 1, a week before the first round of elections. Similarly to the event four years earlier, a big crowd gathered in front of the Parliament on the "Day of Solidarity" where conservative intellectuals, artists and athletes lined up to demonstrate their support for FIDESZ.

In the first round the Socialists lead with $43.21 \%$ of votes cast, while FIDESZ obtained $42.03 \%$, with MDF passing the $5 \%$ threshold by a mere $0.04 \%$ and SZDSZ finishing in third place with $6.5 \%$ of votes (Table 1 ). FIDESZ had two weeks to redefine its strategy in order to have the socialist government replaced. Talks were initiated with MDF, but the party's leader, Ibolya Dávid, refused to negotiate and to "help Orbán into power". The leader of FIDESZ then made a decision to step down from his candidacy and offered the position to Péter Ákos Bod, former President of the Hungarian National Bank during the Antall government, who as an economist had worked closely with MDF and Ibolya Dávid in previous years and who appeared to represent an acceptable compromise for both parties. MDF, however, refused to accept the deal and postponed all further negotiations until the second round of elections were over. On April 23, it became clear that the socialist-liberal government had obtained the necessary majority to stay in office.

The elements of populism (Mény-Surel 2002) that gained momentum within FIDESZ-MPP are as follows:

- An anti-establishment, anti-elite, anti-"political class", nomenclature orientation;

- Siding with the people, civil society, national and rural and ethnic communities against the "cosmopolitan Social-Liberal parties and their allies";

- Blaming institutions such as elections and parliamentarism for manipulating the "popular will" and emphasizing the need for a review of electoral results or even their nullification, and for a repeat of the elections of 2002 and 2006;

- New forms of organizing; for example, building a "Citizens" Alliance" (Polgári Szövetség) with civic society, where national and religious symbols play a role, and with efforts directed at cultural and social community building to establish hegemony beyond the sphere of politics in other social subsystems; 
- Reshaping the structure of the party to provide momentum to spontaneously developed civic initiatives (Citizens' Circles 2002-2005) on the one hand, and dissolving the organizational identities of the centre-right parties within a common framework led by FIDESZ-MPSZ on the other.

These elements of populism emerged partly through the recalling of former experiences, structures and traditions of anti-communist dissent, or reference to Western centre-right party models in Germany (CDU as a Volkspartei) and Italy (Forza Italia). This latter development synthesized these elements already present within the campaign into the political strategy and organizational form at the FIDESZ party conference of May 2003. These organizational and strategic changes were exemplified in a new format as the "FIDESZHungarian Citizens' Alliance" (FIDESZ-Magyar Polgári Szövetség) of civil society, nation and centre-right parties under the strong leadership of Viktor Orbán, and based on the governing role played by FIDESZ. In 2006, FIDESZ supported a popular right-wing mobilization against the re-elected SocialistLiberal government which resulted in violent riots against the leadership of the Socialist Party and its Prime Minister, Ferenc Gyurcsány. FIDESZ tried to rouse its membership against the potential restitution of communism, and competed with the right-wing group "Jobbik" in the extra-parliamentary arena and also after the 2010 parliamentary elections.

\section{AGAINST THE SOCIALIST-LIBERAL GOVERNMENT AND THE CRUSADE AGAINST PRIME MINISTER FERENC GYURCSÁNY}

In 2006, massive rioting started after a secret speech, recorded in Balatonöszöd, on the manipulation of the electoral program by the re-elected Prime Minister Ferenc Gyurcsány was leaked to the public. Rioting escalated during the fiftieth anniversary celebrations of the Hungarian Revolution of 1956. The political mobilization of FIDESZ in 2002 was not repeated during the 2006 electoral campaign. Their civic initiatives were accepted and leaders used as volunteer satellite troops of the party during the campaign. However, a bigger mobilization with its own distinct character (as in 2002) did not take place. FIDESZ lost the elections in 2006 and the Social-Liberal coalition won. After the summer holidays, a tape recording of Prime Minister Gyurcsány was broadcast to the public on September 18, 2006, which contained a hitherto secret speech addressed to the leaders of the Hungarian Socialist Party, expressing his uncensored criticism of their own economic 
policy and electoral program, which was a "lie" in the sense that it could not be implemented because of EU restrictions and stability criteria, which held that further expansion of indebtedness would not be tolerated.

The sudden release of the speech resulted in spontaneous mass gatherings of approximately 10,000 people in front of the Hungarian Parliament on Kossuth Square. The following night some groups of protesters marched to the nearby Hungarian state television headquarters and demanded a broadcast of a declaration in which they called for the resignation of the government and other radical, and basic, changes within Hungarian politics and society. The authorities rejected the demand and asked for police intervention to remove the protesters from the building. As a result, hundreds and thousands of demonstrators from Kossuth Square started a "siege and battle" which lasted until morning, resulting in the withdrawal of the police forces which were weakened under the pressure of a violent rioting mass, which looted and severely damaged the building and broadcasting equipment.

Over the following days, confrontations and "battles" between the police and unofficial demonstrating groups and individuals continued in the streets of Budapest every night. A permanent demonstration at Kossuth Square was tolerated until the 23rd of October where the fiftieth anniversary of the Hungarian Revolution was celebrated with a wide circle of invited guests of the government in the parliament; here police broke up the continuous demonstration after more than one month because of security risks. FIDESZ supported this permanent demonstration in front of the parliament building by sending speakers there almost every day, but rejected street violence and illegal demonstrations in accord with other parties in the parliament.

The dissolution of the permanent demonstration on Kossuth Square resulted in a wave of rioting in other places in Budapest on the 23rd of October and during the celebrations that followed. The peak point occurred when - parallel to and following an official FIDESZ mass gathering in the heart of Budapest - thousands of demonstrators fought against the police, built barricades on the Pest side of Erzsébet Bridge and later burnt them. Erzsébet Bridge played a central role on July 4, 2002, when radical demonstrators blocked traffic for hours, protesting against the electoral victory of the Social-Liberal coalition and rejecting the result because of alleged manipulation by the Socialists. Kossuth Square remained "besieged" by police cordons from October 23, 2006 to March 17, 2007, when under massive criticism from opposition and other liberal voices, the Budapest police declared the place free to be used for demonstrations again. Almost the entire FIDESZ parliamentary group - led by Viktor Orbán - removed the police fence on February 1, 2007 in part of a protest against the illegal violation of human rights. 
The rioting from September 18, 2006 onwards also produced inestimable material losses and personal damage. Policemen and demonstrators suffered severe injuries and private and public property was damaged, not to mention tourism and retail-related losses in Budapest. The loss of prestige for political actors and political institutions and the government's increasing lack of legitimacy lead Hungary to lose its image as a peaceful and orderly place for investment and tourism in the eyes of global media interested in the expected fanfare of the fiftieth anniversary of the Hungarian Revolution, where the portrayal of continuous street fighting between authorities and citizens in Budapest indicated the opposite scenario.

The idea of FIDESZ, the hegemony of the right based on one organizational form, provoked political discussions with other right-wing parties. However, the Hungarian electoral system is of a majoritarian character which helped establish the leading role of the right with the hegemony of the FIDESZCitizens' Alliance, the "Polgári Szövetség", despite political competition from the extreme right party "Jobbik" which was the only real challenger for FIDESZ from the right in the 2010 spring parliamentary elections.

\section{RESULTS OF THE 2010 ELECTION}

The parliamentary elections in Hungary 2010 were held on April 11 and April 25, 2010. They are the sixth free elections that have been held since the end of the communist era. The 386 members of the Parliament are elected using a combined system of party lists and electoral constituencies. In the first round of the elections, the rightwing-conservative party FIDESZ won the absolute majority of seats, enough to form a government on its own (Table $3)$.

In the second round, FIDESZ-KDNP candidates won enough seats to achieve the two-thirds majority required to modify major laws and the country's constitution (Table 4). The two biggest parties of the 1989-90 regime change, the conservative MDF and the liberal SZDSZ, completely lost their seats (Table 2). The election campaign was influenced by the high unemployment rate - nearly eleven percent in March 2010. The socialist MSZP (in a ruling coalition with SZDSZ) was further damaged by a series of corruption scandals involving its members and officials. Consequently, the opposing FIDESZ-KDNP campaigned under the slogan "The time has come!" It promised to create one million jobs over ten years, to boost lending, to support small businesses and to cut taxes. Other major contenders included the Movement for a Better Hungary (Jobbik), a right wing party, and Politics 
Can Be Different (LMP), a green-liberal party founded in February 2009. The Jobbik party was founded in 2003 and won nearly fifteen percent of the votes in the European Parliament elections in June 2009. Its participation in the 2010 elections caused a lot of controversy, as its members used antiRoma and anti-Semitic rhetoric and because party leader Gabor Vona argued that "Hungary belongs to the Hungarians". Both FIDESZ-KDNP and MSZP rejected the possibility of entering into a coalition with Jobbik.

FIDESZ leader Viktor Orbán became the new prime minister, a position he had held from 1998-2002. The 2010 elections ushered in a brand new situation in Hungarian politics: the winner was so strong that the smaller parties had no chance. FIDESZ won in every category if we look at data based on sociological research from the election (gender, places of residence, age, educational level, etc.). The reason for the landslide victory was rooted partly in the nature and logic of the distribution of seats in the Hungarian electoral system, which very much favors the winner, meaning other parties especially smaller ones - are placed at a disadvantageous position, weakening them further. The original idea of this model in 1989 was to make a strong and stable governing majority possible. But in this case it led to a two-thirds majority for the most popular party.

What we may conclude that as a result of reconstructing FIDESZ's development from an anti-Communist protest movement into a successful political party over twenty years is that, in Hungary, there has emerged an influential governing party of right-wing populist character, combined with a tradition of anti-Communist dissent and the new forms of populism in Western democracies. Hence FIDESZ will move between populist mobilization and crisis management. Populist mobilization supplies its voters identified with the "Citizens" (polgárok), but there are the demands of EU, NATO and OECD countries, from which Hungary seeks stable membership and support. Currently (in 2011), FIDESZ as a governing party has to strike a balance between its own populist program, economic and fiscal necessities and constraints as well the high expectations the Hungarian population has of a government which should solve all of the problems still remaining from the transformation to a market economy, liberal democracy and welfare state. This "trilemma" (Offe, 1994) is a heavy burden on the dynamics of the mobilizing/ populist party in government. 


\section{TABLES}

Table 1.

\begin{tabular}{|c|c|c|c|c|c|c|c|c|c|}
\hline & $\begin{array}{l}\text { N } \\
\text { II } \\
\text { 空 }\end{array}$ & $\begin{array}{l}\hat{N} \\
\sum\end{array}$ & $\stackrel{5}{\mathrm{c}}$ & 窐 & $\begin{array}{l}\text { 융 } \\
\text { 음 }\end{array}$ & $\begin{array}{l}0 \\
\frac{1}{1}\end{array}$ & $\begin{array}{l}N \\
\text { Nิ } \\
\text { Nิ }\end{array}$ & 竞 & $\sum_{j}^{\circ}$ \\
\hline 1990 & 5.7 & 8.5 & 42.8 & - & - & 11.4 & 24.1 & 5.4 & - \\
\hline 1994 & 5.1 & 54.1 & 9.8 & 0 & - & 6.7 & 17.6 & 5.7 & - \\
\hline 1998 & 38.1 & 34.7 & $\begin{array}{c}\text { with FIDESZ: } \\
12.5\end{array}$ & 3.6 & - & 12.4 & 6.2 & 0 & - \\
\hline 2002 & $\begin{array}{c}48.7 \text { (with } \\
\text { MDF) }\end{array}$ & 46.11 & $\begin{array}{l}\text { (only with } \\
\text { FIDESZ) }\end{array}$ & 0 & - & 0 & 5.1 & 0 & - \\
\hline 2006 & 42.0 & 48.2 & 2.8 & - & - & & 4.6 & & - \\
\hline 2010 & $\begin{array}{l}68.1 \text { (with } \\
\text { KDNP) }\end{array}$ & 15.2 & 0 & - & 12.1 & & 0 & & 4.1 \\
\hline
\end{tabular}

Source: National Election Office, www.valasztas.hu

Meaning of party names and acronyms:

FIDESZ (Fiatal Demokraták SzÖvetsége, Alliance of Young Democrats), used this acronym at the 1990 and 1994 elections. The acronym was changed in 1998 to FIDESZ - MPP (FIDESZMagyar Polgári Párt, FIDESZ-Hungarian Citizens' Party), and at the May 2003 conference the acronym FIDESZ - MPSZ (FIDESZ-Magyar Polgári Szövetség, FIDESZ -Hungarian Citizens' Alliance) appeared. Within the alliance there are different social and political organizations, among them, the Christian Democratic Party (KDNP), which was an autonomous party but now is a satellite organization of FIDESZ, despite having a leadership of its own, a faction in the parliament and members in the government. At present we may see the Alliance as one political unit with organizational differentiation.

Független Kisgazda és Földmunkás Párt, FKGP, Independent Smallholders' Party

Keresztény Demokrata Néppart, KDNP, Christian Democratic People's Party

Magyar Demokrata Fórum, MDF, Hungarian Democratic Forum

Magyar Igazság és Élet PÁrtja, MIÉP, Party of Hungarian Life and Truth

Magyar Szocialista PÁRt, MSZP, Hungarian Socialist Party

Szabad Demokraták Szövetsége, SZDSZ, Alliance of Free Democrats

JOBBIK, The Movement for a Better Hungary

Lehet más A POLITIKa, LMP, Politics Can Be Different 
Table 2 Results of 2010 elections -

Number of Parliamentary Representatives: 386

\begin{tabular}{|c|c|c|c|c|c|}
\hline Parties & $\begin{array}{l}\text { In single } \\
\text { member } \\
\text { constituency }\end{array}$ & On regional list & On national list & Total & $\begin{array}{l}\text { Proportion of } \\
\text { Parliamentary } \\
\text { mandates }\end{array}$ \\
\hline $\begin{array}{l}\text { FIDESZ - } \\
\text { HUNGARIAN } \\
\text { CIVIC UNION } \\
\text { KDNP }\end{array}$ & 1 & & & 1 & $0.26 \%$ \\
\hline $\begin{array}{l}\text { FIDESZ - } \\
\text { HUNGARIAN } \\
\text { CIVIC UNION } \\
\text { KDNP }\end{array}$ & 167 & 87 & 3 & 262 & $67.88 \%$ \\
\hline HSP & 2 & 28 & 29 & 59 & $15.28 \%$ \\
\hline $\begin{array}{l}\text { Jobbik } \\
\text {-MOVEMENT } \\
\text { FOR A BETTER } \\
\text { HUNGARY } \\
\end{array}$ & & 26 & 21 & 47 & $12.18 \%$ \\
\hline $\begin{array}{l}\text { LMP -POLITICS } \\
\text { CAN BE } \\
\text { DIFFERENT }\end{array}$ & & 5 & 11 & 16 & $4.15 \%$ \\
\hline Independent & 1 & & & 1 & $0.26 \%$ \\
\hline Total & 176 & 146 & 64 & 386 & $100.00 \%$ \\
\hline
\end{tabular}

Source: National Electional Office, www.valasztas.hu

Table 3

\begin{tabular}{|l|c|c|c|c|}
\hline Parties & Votes & List mandate & $\begin{array}{c}\text { Direct } \\
\text { mandate }\end{array}$ & Overall \\
\hline FIDESZ/KDNP & $52.73 \%$ & $87 \%$ & $119 \%$ & $206 \%$ \\
\hline MSZP & $19.31 \%$ & $28 \%$ & $0 \%$ & $28 \%$ \\
\hline Jobbik & $16.67 \%$ & $26 \%$ & $0 \%$ & $26 \%$ \\
\hline LMP & $7.4 \%$ & $5 \%$ & $0 \%$ & $5 \%$ \\
\hline MDF & $2.66 \%$ & $0 \%$ & $0 \%$ & $0 \%$ \\
\hline Other & $1.17 \%$ & $0 \%$ & $0 \%$ & $0 \%$ \\
\hline Total & $100 \%$ & 146 & 119 & 265 \\
\hline
\end{tabular}

Source: www. valasztas.hu

1. Table: results in the first round 
Table 4 In the second round FIDESZ won 54 from 57 constituencies.

\begin{tabular}{|l|c|c|c|c|}
\hline Parties & Votes & List mandates & Direct mandate & Overall \\
\hline FIDESZ/KDNP & & $3 \%$ & $54 \%$ & $57 \%$ \\
\hline MSZP & & $29 \%$ & $2 \%$ & $31 \%$ \\
\hline Jobbik & & $21 \%$ & $0 \%$ & $21 \%$ \\
\hline LMP & & $11 \%$ & $0 \%$ & $11 \%$ \\
\hline MDF & & $0 \%$ & $0 \%$ & $0 \%$ \\
\hline Other & & $0 \%$ & $1 \%$ & $1 \%$ \\
\hline Total & $100 \%$ & 64 & 57 & 121 \\
\hline
\end{tabular}

Source: www.valasztas.hu

2. Table: Results in the second round

\section{REFERENCES}

Arato, Andrew (1992), 'Civil Society in Emerging Democracies: Poland and Hungary', in: M. L. Nugent (ed.), From Leninism to Freedom, Westview, Boulder, Co.,12753.

Ash, Timothy Garten (1990), We the People. The Revolution of '89, Granta Books, Cambridge.

Bozóki, András (1992) (eds.): Tiszta lappal. A FIDESZ a magyar politikában. 19881991. FIDESZ, Budapest.

Bozóki, András (1988), 'Critical Movements and Ideologies in Hungary', Südosteuropa, Nos. 7-8, 377-388.

Bozóki, András (1999-2000), A rendszerváltás forgatókönyve, Vols. 1-7, Magvető, Budapest.

Bozóki, András (ed.) (1992), Tiszta lappal. A FIDESZ a magyar politikában. 19881991, FIDESZ, Budapest.

Csizmadia, Ervin (1995), A magyar demokratikus ellenzék, Vols. 1-3, T-Twins, Budapest.

Ekiert, Grzegorz (1991), Democratic Processes in East Central Europe, in: British Journal of Political Science No. 3. 285-315.

Ekiert, Grzegorz-Kubik, Jan (1998): Contentious Politics in New Democracies: East Germany, Hungary, Poland, and Slovakia, 1989-1993, in: World Politics No. 4. July, 507-547.

Falk, Barbara J. (2003): The Dilemmas of Dissence in East Central Europe.CEU U.P: Budapest-New York.

Glenn III, John K. (2001): Framing Democracy. Civil Society and Civic Movements in Eastern Europe. Stanford U.P. Stanford (Cal.).

Haraszti, Miklós (1990), 'The Beginning of Civil Society: The Independent Peace Movement and the Danube Movement in Hungary', in Vladimir Tismaneanu (ed.), In Search of Civil Society, Routledge, New York, 71-88. 
Joppke, Christian (1994), 'Revision, Dissidence, Nationalism: Opposition in Leninist Regimes', The British Journal of Sociology, Vol. 45, No. 4, 542-561.

Judt, Tony (1988), 'The Dilemmas of Dissidence', East European Politics and Societies, Vol. 2, 185-240.

Kende, Pierre-Smolar, Aleksandr (1989), Die Rolle oppositioneller Gruppen am Vorabend der Demokratisierung in Polen und Ungarn (1987-1989), INDEX, Köln.

Knabe, Hubertus (1988), 'Neue soziale Bewegungen im Sozialismus', Kölner Zeitschrift für Soziologie und Sozialpsychologie, Vol. 40, 551-569.

Körösényi, András-csba Tóth-Gábor Török (2009), The Hungarian Political System. Corvinus DKMK, Budapest.

Köszeg, Ferenc (1999), 'Zum Charakter des politischen Umbruchs in Ungarn', in Dagmar Unverhau (ed.), Lustration, Akteneröffnung, demokratischer Umbruch in Polen, Tschechien, der Slowakei und Ungarn, LIT-Verlag, Hannover, 151-159.

Machos, Csilla (1992), "Von der ,alten“ zur „,neuen“ ungarischen Opposition. Demokratische Charta '91', Berliner Debatte Initial, No. 4, 57-68.

Machos, Csilla (1993), 'FIDESZ - Der Bund Junger Demokraten. Zum Porträt einer Generationspartei' Südosteuropa, No. 1, 1-26.

Mény, Yves-Surel, Yves (2002), (eds.): Democracies and the Populist Challenge. Palgrave: New York.

Miszlivetz, Ferenc (1989), 'Emerging Grassroots Movements in Eastern Europe: Toward a Civil Society?', in: Vera Gáthy (ed.), State and Civil Society, MTA, Budapest, 99-113.

Mudde, Cas-Kopecky, Peter (2002), The Two Sides of Euroscepticism.Party Positions on European Integration in East Central Europe, in: European Union Politics No. 3. 297-326.

Mudde, Cas-Kopecky, Peter (2003) (eds.): Uncivil Society? Contentious Politics in Eastern Europe. Routledge, London.

Offe, Claus (1994), Der Tunnel am Ende des Lichts. Erkundungen der politischen Transformation in Neuen Osten. Campus.Frankfurt/New York.

Pollack, Detlef-Wielghos, Jan (2004) (eds.): Dissent and Opposition in Communist Eastern Europe. Origins of Civil Society and Democratic Transition. Ashgate. Aldershot.

Ramet, Sabrina P. (1991), Social Currents in Eastern Europe, Duke UP, Durham. Schöpflin, George (1979), 'Opposition and Para-Opposition. Critical Currents in Hungary, 1968-1978', in R. Tökés (ed.), Opposition in Eastern Europe, MacMillan, London, 142-187.

Szabó, Máté (1991), 'Changing Patterns within the Mobilization of Alternative Movements in Hungary', in G. Szoboszlai (ed.), Democracy and Political Transformation, HPSA, Budapest, 310-325.

Tőkés, Rudolf L. (1998), Hungary's Negotiated Revolution. Economic Reform, Social

Change and Political Succession 1957-1990.Cambridge Mass: Cambridge U.P:

Zald, Mayer N.-McCarthy, John D.(eds.), (1990) Social Movements in an Organizational Society. Transaction. London. 